\title{
Ganoderma lucidum inhibits proliferation of human breast cancer cells by down-regulation of estrogen receptor and NF-kB signaling
}

\author{
JIAHUA JIANG $^{1}$, VERONIKA SLIVOVA $^{1}$ and DANIEL SLIVA ${ }^{1-3}$ \\ ${ }^{1}$ Cancer Research Laboratory, Methodist Research Institute; ${ }^{2}$ Department of Medicine, and \\ ${ }^{3}$ Indiana University Cancer Center, School of Medicine, Indiana University, Indianapolis, IN, USA
}

Received February 15, 2006; Accepted April 10, 2006

\begin{abstract}
Ganoderma lucidum, an oriental medical mushroom, has been used in Asia for the prevention and treatment of a variety of diseases, including cancer. We have previously demonstrated that G. lucidum inhibits growth and induces cell cycle arrest at $\mathrm{G}_{0} / \mathrm{G}_{1}$ phase through the inhibition of $\mathrm{Akt} / \mathrm{NF}-\kappa \mathrm{B}$ signaling in estrogen-independent human breast cancer cells. However, the molecular mechanism(s) responsible for the inhibitory effects of G. lucidum on the proliferation of estrogen-dependent (MCF-7) and estrogenindependent (MDA-MB-231) breast cancer cells remain to be elucidated. Here, we show that G. lucidum inhibited the proliferation of breast cancer MCF-7 and MDA-MB-231 cells by the modulation of the estrogen receptor (ER) and NF- $\mathrm{BB}$ signaling. Thus, G. lucidum down-regulated the expression of ER $\alpha$ in MCF-7 cells but did not effect the expression of ERß in MCF-7 and MDA-MB-231 cells. In addition, $G$. lucidum inhibited estrogen-dependent as well as constitutive transactivation activity of ER through estrogen response element (ERE) in a reporter gene assay. G. lucidum decreased TNF- $\alpha$-induced (MCF-7) as well as constitutive (MDA-MB-231) activity of NF- $\mathrm{KB}$. The inhibition of ER and $\mathrm{NF}-\kappa \mathrm{B}$ pathways resulted in the down-regulation of expression of c-myc, finally suppressing proliferation of estrogen-dependent as well as estrogen-independent cancer cells. Collectively, these results suggest that $G$. lucidum inhibits proliferation of human breast cancer cells and contain biologically active compounds with specificity against estrogen receptor and NF-кB signaling, and implicate G. lucidum as a suitable herb for chemoprevention and chemotherapy of breast cancer.
\end{abstract}

Correspondence to: Dr D. Sliva, Cancer Research Laboratory, Methodist Research Institute, 1800 N. Capitol Avenue, E504, Indianapolis, IN 46202, USA

E-mail: dsliva@clarian.org

Key words: breast cancer, proliferation, estrogen receptor, NF-кB, c-myc

\section{Introduction}

Estrogens exert their biological effects such is the induction of cell proliferation through the interaction with estrogen receptor-alpha $(E R \alpha)$ and ER-beta (ERß) (1-3). The liganded ER forms homo-/hetero-dimers, translocate into nucleus and activate transcription of target genes through the binding to estrogen response elements (EREs) in their promoter region $(2,4-6)$. The activation of $\mathrm{ER} \alpha$ stimulates cell proliferation while ERß has an opposite effect (7-9). Therefore, selective estrogen receptor modulators (SERMs) are widely used for the treatment of breast cancer in ER $\alpha$-positive breast tumors $(10,11)$. However, breast cancer often progresses from the estrogen-dependent, nonmetastatic phenotype (ER $\alpha$ - and ERß-positive) to the estrogen-independent, metastatic phenotypes (ER $\alpha$-negative and ERß-positive) (11).

Constitutively active transcription factor nuclear factor- $\kappa \mathrm{B}$ $(\mathrm{NF}-\mathrm{\kappa B})$ and increased expression of c-myc were found in breast cancer cells $(12,13)$ and linked to their high proliferative potential $(3,13,14)$. Since the expression of c-myc is regulated

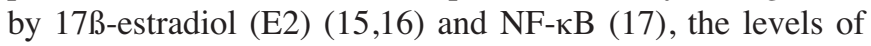
$\mathrm{c}$-myc in estrogen-dependent and estrogen-independent breast cancer cells can be modulated through the inhibition of ER and NF- $\mathrm{KB}$ signaling pathways. We and others have demonstrated that the increased activity of $\mathrm{NF}-\mathrm{\kappa B}$ is associated with the invasive behavior and aggressive tumor growth of ER $\alpha$-negative breast cancer cells, and found that the inhibition of NF- $\mathrm{NB}$ results in the suppression of invasiveness and growth of these cells $(12,18)$.

The extracts from a medicinal mushroom Ganoderma lucidum (Reishi) have been widely used in Asian countries to treat various human diseases, including cancers. The anticancer properties of G. lucidum have been attributed to a variety bioactive compounds including polysaccharides and lanostanebased triterpenes $(19,20)$. We have recently demonstrated that transcription factor NF- $\mathrm{BB}$ controls invasive behavior of highly metastatic breast cancer cells (18), and that G. lucidum inhibits invasiveness of breast cancer cells through the suppression of $\mathrm{NF}-\kappa \mathrm{B}$, resulting in the down-regulation of the expression of urokinase-type plasminogen activator (uPA) and its receptor (uPAR) (21). We have also found that G. lucidum inhibits the growth of breast cancer cells through the cell cycle arrest at $\mathrm{G}_{0} / \mathrm{G}_{1}$, which was mediated by the suppression of Akt/NF-кB 
signaling and the down-regulation of expression of cyclin D1 (22).

In the present study, we investigated the molecular mechanism(s) responsible for the inhibitory effects of G. lucidum on the proliferation of estrogen-dependent MCF-7 (ER $\alpha$-, ERß-positive) and estrogen-independent MDA-MB-231 (ER $\alpha$-negative, ERß-positive) human breast cancer cells. We demonstrated that $G$. lucidum down-regulates the expression of ER $\alpha$, inhibits estrogen-inducible ER transactivation and inhibits TNF- $\alpha$-stimulated activation of NF- $\mathrm{KB}$ in MCF-7 cells. G. lucidum also suppressed constitutive activity of ERE and NF- $\kappa \mathrm{B}$ in MDA-MB-231 cells. The inhibition of inducibleas well as constitutive-estrogen receptor and NF- $\mathrm{kB}$ pathways resulted in the down-regulation of expression of c-myc, finally resulting in the suppression of proliferation of MCF-7 and MDA-MB-231 breast cancer cells.

\section{Materials and methods}

Materials. G. lucidum (Reishimax) was purchased from Pharmanex (Provo, UT). According to the manufacturer, this sample contains $13.5 \%$ polysaccharides and $6 \%$ triterpenes. Further analysis by LC-MS demonstrated the presence of ganoderic acids $\mathrm{A}, \mathrm{F}$ and $\mathrm{H}$, which can be used for the standardization of G. lucidum (Thyagarajan et al, unpublished data). G. lucidum was dissolved in sterile water at a concentration of $50 \mathrm{mg} / \mathrm{ml}$ and stored at $4^{\circ} \mathrm{C}$. $17 ß$-estradiol was purchased from Sigma (St. Louis, MO), tamoxifen was purchased from Calbiochem (La Jolla, CA).

Cell culture. The human breast cancer cell lines (MCF-7 and MDA-MB-231) were obtained from ATCC (Manassas, VA). MCF-7 and MDA-MB-231 cells were maintained in phenol red-free Dulbecco's modified Eagle's medium (DMEM) containing penicillin $(50 \mathrm{U} / \mathrm{ml})$, streptomycin $(50 \mathrm{U} / \mathrm{ml})$, and $10 \%$ fetal bovine serum (FBS). 293T/NF-kB-luc cell line was obtained from Panomics (Redwood City, CA). 293T/NF-кBluc cells were maintained in DMEM containing penicillin (50 U/ml), streptomycin $(50 \mathrm{U} / \mathrm{ml})$, hygromycin $(100 \mu \mathrm{g} / \mathrm{ml})$ and $10 \%$ FBS. Media and supplements were from Invitrogen (Grand Island, NY). FBS and Charcoal/Dextran treated FBS (CDFBS) were obtained from Hyclone (Logan, UT). Dulbecco's phosphate-buffered saline (DPBS) was purchased from Cambrex Bio Science Walkersville, Inc. (Walkersville, $\mathrm{MD)}$.

Cell proliferation assay. Cell proliferation was determined by the tetrazolium salt method (MTT method), according to the manufacturer's instructions (Promega, Madison, WI). Briefly, MCF-7 and MDA-MB-231 cells (2.5x103/well) were cultured in a 96-well plate and treated with G. lucidum $(0-0.25 \mathrm{mg} / \mathrm{ml})$ for 24 and $48 \mathrm{~h}$. At the end of the incubation period, the cells were harvested and absorption was determined with an ELISA plate reader at $570 \mathrm{~nm}$. Data points represent mean $\pm \mathrm{SD}$ in one experiment repeated at least twice.

Real-time reverse transcription-PCR. Real-time RT-PCR was used to determine the expression levels of ER $\alpha$ and ER $\beta$ mRNA in human breast cancer cells. The total RNA from breast cancer cells was isolated by RNeasy Mini kit (Qiagen,
Valencia, CA) according to the manufacturer's instructions. Reverse transcription was performed as previously described (23). The PCR primers and TaqMan probes for ER $\alpha, E R ß$, and $B$-actin were synthesized from MWG (High Point, NC). PCR was performed by mixing $5 \mu 1$ of RT product with 2X QuantiTect Probe PCR master mix (Qiagen), and $0.375 \mu 1$ of primer/probe mixture in a total of $25 \mu 1$. Real-time quantitative PCR analysis was performed using an ABI PRISM 7700 Sequence Detection System (Applied Biosystems, Foster City, CA). The amplifications were performed in duplicate for each sample and the PCR conditions were as follows: initial incubation at $50^{\circ} \mathrm{C}$ for $2 \mathrm{~min}$, denaturation at $95^{\circ} \mathrm{C}$ for $10 \mathrm{~min}$, followed by 40 cycles at $95^{\circ} \mathrm{C}$ for $15 \mathrm{sec}$, and $60^{\circ} \mathrm{C}$ for $1 \mathrm{~min}$. We analyzed the relative quantitation of gene expression by the comparative $\mathrm{C}_{\mathrm{T}}$ $\left(\Delta \Delta C_{T}\right)$ method (24). Briefly, the threshold cycle $\left(C_{T}\right)$ was obtained as the fractional cycle number at which the amount of amplified target reached a fix threshold. Data normalization was performed by subtracting $\mathrm{C}_{\mathrm{T}}$ value of the $B$-actin from that of the target gene. The $\Delta \Delta C_{T}$ was calculated as the difference of the normalized $\mathrm{C}_{\mathrm{T}}$ value $\Delta \mathrm{C}_{\mathrm{T}}$ ) of the treatment and control samples. $\Delta \Delta \mathrm{C}_{\mathrm{T}}=\Delta \mathrm{C}_{\mathrm{T} \text { treatment }}-\Delta \mathrm{C}_{\mathrm{T} \text { control }}$. The comparative expression level of target genes is equal to $2-\triangle \triangle C T$.

DNA transfection and luciferase assay. MCF-7, MDA-MB-231 and $293 \mathrm{~T} / \mathrm{NF}-\kappa \mathrm{B}-\mathrm{luc}$ cells $\left(2.5 \times 10^{5} /\right.$ well $)$ were seeded into 6 -well plates in DMEM with $10 \%$ FBS prior to transfection. Transient transfections were performed with the Effectene reagent (Qiagen) according to the manufacturer's instructions. Briefly, the cells were transfected with ERE-II-luc (8) or NF-кB-luc (BD Biosciences Clontech, Palo Alto, CA) reporter constructs $(1 \mu \mathrm{g})$ and $B$-galactosidase expression vector pCH110 $(1 \mu \mathrm{g})$ while $293 \mathrm{~T} / \mathrm{NF}-\kappa \mathrm{B}-\mathrm{luc}$ cells were transfected with pSG5 or ER $\alpha$ (25) or ERß (26) expression vector constructs $(1 \mu \mathrm{g})$ and $\beta$-galactosidase expression vector pCH110 $(1 \mu \mathrm{g})$. Twenty hours after transfection, cells were washed once with DPBS and the medium was replaced with DMEM with $2 \%$ CDFBS. Cells were treated with E2 (10 nM), tamoxifen $(1 \mu \mathrm{M})$, and G. lucidum $(0.5 \mathrm{mg} / \mathrm{ml})$ for $20 \mathrm{~h}$ followed by the treatment with TNF- $\alpha(50 \mathrm{ng} / \mathrm{ml})$ for an additional $4 \mathrm{~h}$. $\beta$-glactosidase activity was measured in cell lysates, as previously described (18). Normalized amounts (equal numbers $\beta$-galactosidase units) of cell extracts were used in luciferase assay using Lmax luminometer (Molecular Devices, Sunnyvale, CA). Data points represent the mean \pm SD of three independent transfection experiments.

Preparation of nuclear and whole cell extract. MCF-7 and MDA-MB-231 cells $\left(1 \times 10^{7}\right)$ were treated with G. lucidum $(0-1.0 \mathrm{mg} / \mathrm{ml})$ for $24 \mathrm{~h}$. Whole cell extracts were prepared as described (22). Nuclear extracts were isolated from cells resuspended with $0.5 \mathrm{ml}$ of ice-cold RSB lysis buffer $(10 \mathrm{mM}$ Tris- $\mathrm{HCl} \mathrm{pH} \mathrm{7.4,} 10 \mathrm{mM} \mathrm{NaCl}, 1 \mathrm{mM}$ DTT, and protease inhibitor cocktail Complete ${ }^{\mathrm{TM}}$ ), by dounce homogenization. The nuclei were collected by centrifugation and the nuclear pellet was resuspended in $3 \mathrm{Vol}$ of Buffer C (20\% glycerol, $20 \mathrm{mM}$ HEPES pH 7.9, $420 \mathrm{mM} \mathrm{NaCl}, 1.5 \mathrm{mM} \mathrm{MgCl}_{2}, 0.2 \mathrm{mM}$ EDTA, $0.2 \mathrm{mM}$ PMSF, $1 \mathrm{mM}$ DTT, $100 \mu \mathrm{M} \mathrm{Na}_{3} \mathrm{VO}_{4}$ and 
protease inhibitor cocktail Complete ${ }^{\mathrm{TM}}$ ), incubated for $30 \mathrm{~min}$, and the final supernatant (nuclear extract) collected by centrifugation. The protein concentration in whole cell and nuclear extract was determined according to the manufacturer's protocol (Bio-Rad Laboratories, Hercules, CA).

Electrophoretic mobility shift assay (EMSA). Oligonucleotide probes containing consensus sequences for ERE and NF-kB binding sites were purchased from Santa Cruz Biotechnology and Promega (Madison, WI), respectively. EMSA for NF- $\mathrm{kB}$ was performed as previously described (18). EMSA for ERE was carried out in binding buffer [5\% glycerol, $20 \mathrm{mM}$ HEPES $\mathrm{pH} 7.9,100 \mathrm{~mm} \mathrm{KCl}, 1 \mathrm{mM}$ EDTA, $2.5 \mathrm{mM}$ DTT, and $2.0 \mu \mathrm{g}$ poly-dIdC] with $5 \mu \mathrm{g}$ of nuclear protein on ice for $20 \mathrm{~min}$. One $\mu 1(40,000 \mathrm{cpm})$ of $\left[{ }^{32} \mathrm{P}\right]$-labeled ERE probe was added to the reaction mixture and incubated for another $20 \mathrm{~min}$ at room temperature. The reaction mixture was then separated on a $4.5 \%$ PAGE gel in $0.25 \mathrm{X}$ Tris/borate/EDTA (TBE) buffer. The specificity was confirmed by competitive EMSA with cold ERE oligonucleotide or unrelated DNA (URL), and supershift analysis with anti-ER $\alpha$ or anti-ERß antibody (Santa Cruz Biotechnology, Santa Cruz, CA).

Western blot analysis. Equal amounts of proteins (20 $\mu \mathrm{g} /$ lane) were separated on 4-12\% SDS-PAGE and transferred to a PVDF membrane (Millipore, Bedford, MA). The membrane was incubated with the corresponding primary antibodies diluted 1:1000 in blocking solution, as follows: a mouse anti-ER $\alpha$ monoclonal antibody, a rabbit anti-ERß polyclonal antibody, a mouse anti-c-Myc monoclonal antibody, and a mouse anti-actin monoclonal antibody (Santa Cruz Biotechnology). Anti-mouse or anti-rabbit secondary antibodies (Amersham Biosciences, Buckinghamshire, UK) were used for detection and visualization by the ECL Western blotting detection system (Amersham Biosciences).

Densitometric analysis. Autoradiograms of the Western blots were scanned with hp scanjet $5470 \mathrm{c}$ scanner. The optical densities of ER $\alpha, E R \beta, c-m y c$ and $\beta$-actin proteins on the film were quantified and analyzed with the UN-SCAN-IT software (Silk Scientific, Orem, UT). The ratios of ER $\alpha$ /actin, ERß/actin, and c-myc/actin were calculated by standardizing the ratios of each control to the unit value.

\section{Results}

G. lucidum inhibits proliferation of non-invasive as well as invasive breast cancer cells. We have recently demonstrated that an extract from medicinal mushroom G. lucidum inhibits proliferation of highly invasive human breast cancer cells (22). In order to evaluate effects of G. lucidum on the growth of non-invasive, estrogen-dependent (MCF-7), and highlyinvasive, estrogen-independent (MDA-MB-231) breast cancer cells, the cells were treated with $G$. lucidum $(0-0.25 \mathrm{mg} / \mathrm{ml})$ for 24 and 48 h. As seen in Fig. 1A, G. lucidum inhibits the growth of MDA-MB-231 cells in a dose- and-time dependent manner. However, G. lucidum demonstrates more profound effect on MCF-7 cells since the concentration of $31 \mu \mathrm{g} / \mathrm{ml}$ inhibited proliferation of MCF-7 cells by $47-61 \%$ within 24-48 h, whereas the same dose inhibited proliferation of
$\mathbf{A}$

MDA-MB-231

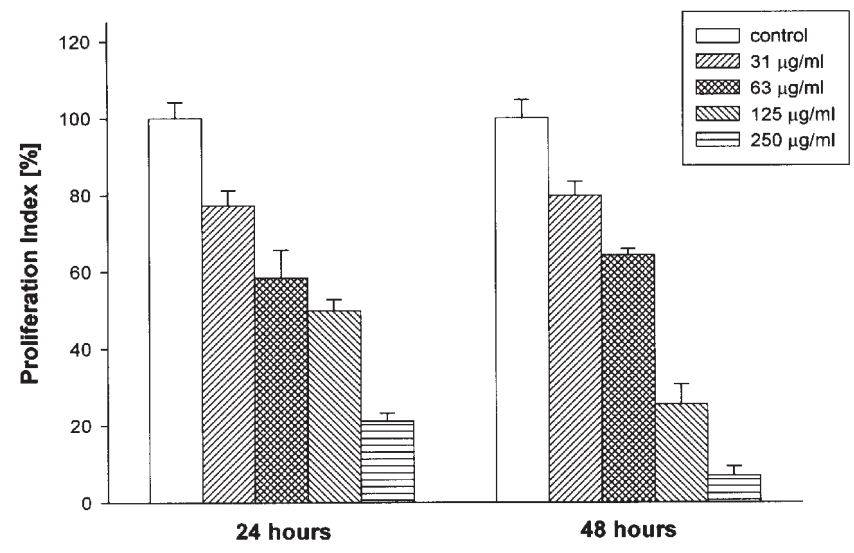

B

MCF-7

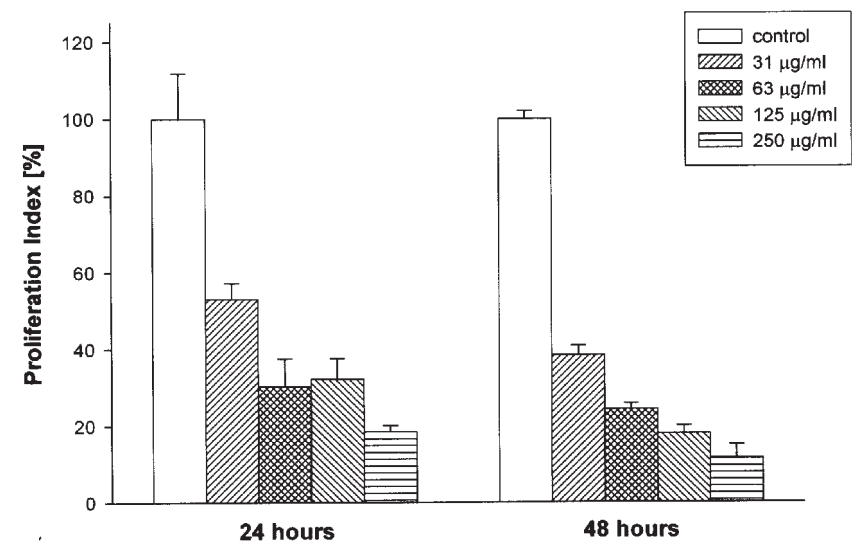

Figure 1. G. lucidum inhibits proliferation of breast cancer cells. (A) MDAMB-231, (B) MCF-7 cells were treated with $0-250 \mu \mathrm{g} / \mathrm{ml}$ of G. lucidum. Proliferation was assessed after 24 and $48 \mathrm{~h}$, as described in Materials and methods. Each bar represents the mean $\pm \mathrm{SD}$ of three experiments.

MDA-MB-231 cells only by 23-20\%, respectively (Fig. 1B). The inhibition of proliferation is not caused by the cytotoxicity of G. lucidum because, as we previously demonstrated, the viability of breast cancer cells is not affected by the concentration up to $1.0 \mathrm{mg} / \mathrm{ml}$ (22). These results suggest that estrogen-dependent (MCF-7) cells are more sensitive to $G$. lucidum than estrogen-independent (MDA-MB-231) cells.

Effect of G. lucidum on the expression of ER alpha and ER beta in breast cancer cells. To confirm the status of estrogen receptors in breast cancer cells, the whole cell lysates were prepared from MCF-7 and MDA-MB-231 cells and subjected to Western blot analysis with anti-ER $\alpha$ and anti-ERß antibody, respectively. As expected, MCF-7 estrogen-dependent breast cancer cells express ER $\alpha$ and ERß, whereas estrogenindependent MDA-MB-231 cells express only ERß (Fig. 2A). In order to determine whether the inhibition of cell growth is related to the status of estrogen receptors, we examined the 
B

A

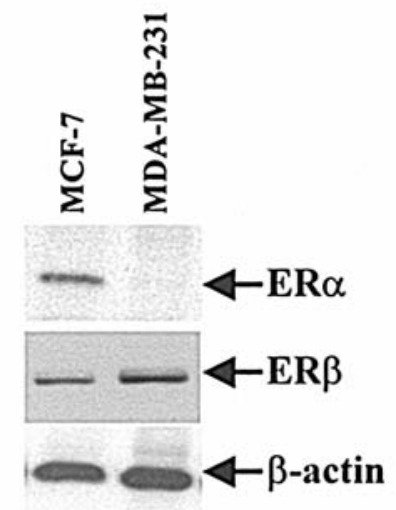

C

MCF-7

$\begin{array}{lllll}0 & 0.25 & 0.5 & 1.0 & \text { G. lucidum }(\mathrm{mg} / \mathrm{ml})\end{array}$
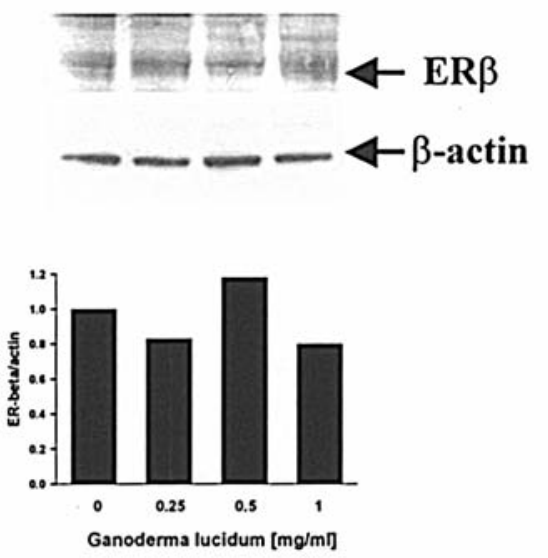

$\mathbf{E}$

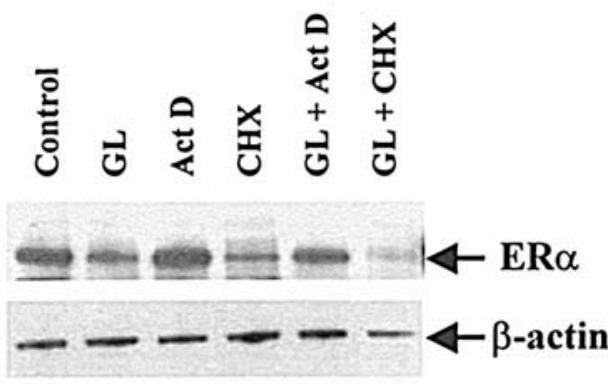

effects of G. lucidum on the expression of ER $\alpha$ and ERß in these cells. MCF-7 and MDA-MB-231 cells were treated with G. lucidum $(0-1.0 \mathrm{mg} / \mathrm{ml})$ for $24 \mathrm{~h}$ and the expression of $\mathrm{ER} \alpha$ and ERß mRNA was evaluated by the real-time-PCR. The treatment with G. lucidum did not change mRNA of ER $\alpha$ or ERß in MCF-7 cells or ERß in MDA-MB-231 cells (not
MCF-7
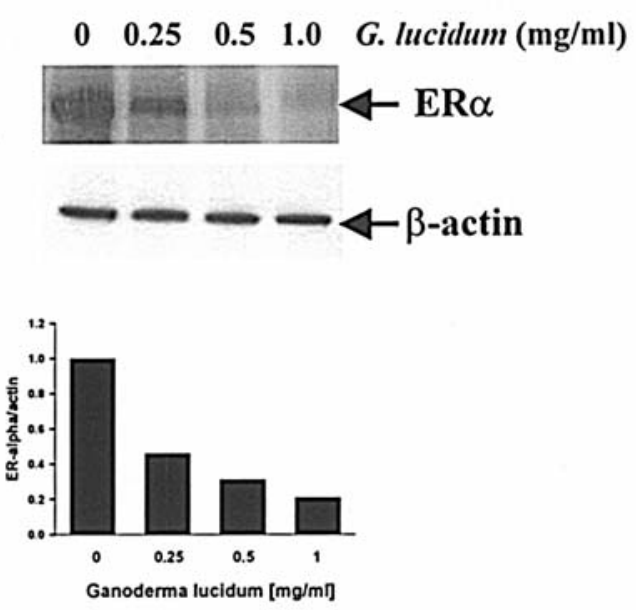

D

MDA-MB-231

$\begin{array}{lllll}0 & 0.25 & 0.5 & 1.0 & \text { G. lucidum }(\mathrm{mg} / \mathrm{ml})\end{array}$
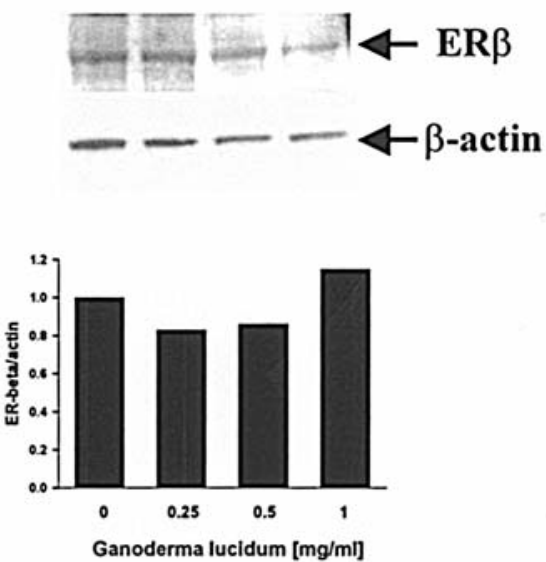

Figure 2. Effect of G. lucidum on the expression of ER $\alpha$ and ERß in breast cancer cells. (A) Whole cell extracts from MCF-7 and MDA-MB-231 cells were subjected to Western blot analysis with anti-ER $\alpha$ and anti-ER $\beta$ antibodies. The equal protein loading was verified with anti- $\beta$-actin antibody. The results are representative of three separate experiments. (B) MCF-7 cells were treated with G. lucidum $(0-1.0 \mathrm{mg} / \mathrm{ml})$ for $24 \mathrm{~h}$ and whole cell extracts were subjected to Western blot analysis with anti-ER $\alpha$ antibody. The equal protein loading was verified with anti- $\beta$-actin antibody and the expression of ER $\alpha$ quantified by densitometry as described in Materials and methods. The results are representative of three separate experiments. (C) MCF-7 cells were treated with G. lucidum $(0-1.0 \mathrm{mg} / \mathrm{ml})$ for $24 \mathrm{~h}$ and whole cell extracts were subjected to Western blot analysis with anti-ERß antibody. The equal protein loading was verified with anti- $\beta$-actin antibody and the expression of ERß quantified by densitometry as described in Materials and methods. The results are representative of three separate experiments. (D) MDA-MB-231 cells were treated with G. lucidum $(0-1.0 \mathrm{mg} / \mathrm{ml})$ for $24 \mathrm{~h}$ and whole cell extracts were subjected to Western blot analysis with antiERß antibody. The equal protein loading was verified with anti- $\beta$-actin antibody and the expression of ERß quantified by densitometry as described in Materials and methods. The results are representative of three separate experiments. (E) MCF-7 cells were treated with vehicle (control), G. lucidum (GL, $0.5 \mathrm{mg} / \mathrm{ml}$ ), Actinomycin D (ActD, $1 \mu \mathrm{g} / \mathrm{ml}$ ), cycloheximide (CHX, $10 \mu \mathrm{g} / \mathrm{ml}$ ), or the combination of GL with ActD or GL with CHX for $24 \mathrm{~h}$, and whole cell extracts were subjected to Western blot analysis with anti-ER $\alpha$ antibody. The equal protein loading was verified with anti- $\beta$-actin antibody. The results are representative of three separate experiments. 
shown). In contrast, G. lucidum markedly decreased the levels of $\mathrm{ER} \alpha$ protein in MCF-7 cells in a dose-dependent manner (Fig. 2B), whereas the same treatment did not affect the expression of ERß (Fig. 2C). In addition, the expression of and ERß was also not affected by G. lucidum in MDA-MB-231 cells (Fig. 2D). To clarify the mechanism of regulation of ER $\alpha$ expression in breast cancer cells, MCF-7 cells were treated with G. lucidum $(0.5 \mathrm{mg} / \mathrm{ml})$, inhibitor of transcription Actinomycin D (Act D, $1 \mu \mathrm{g} / \mathrm{ml}$ ), and inhibitor of translation cycloheximide (CHX, $10 \mu \mathrm{g} / \mathrm{ml}$ ). As seen in Fig. 2E, G. lucidum as well as CHX or the combination of both markedly inhibited the expression of ER $\alpha$, whereas Act D or the combination of ActD with G. lucidum did not markedly change the expression of ER $\alpha$ in MCF-7 cells. These results suggest that different mechanisms regulate expression of ER $\alpha$ and ERß, and that G. lucidum regulates expression of ER $\alpha$ at the translational level.

G. lucidum inhibits estrogen receptor mediated transcription activity in breast cancer cells. Natural estrogenic compounds mediate their transcriptional activity through the interaction with ER $\alpha$ and ERß (27). As we show above, G. lucidum inhibits proliferation of breast cancer cells expressing both $E R \alpha / E R \beta$ or only ERß. In order to determine whether the effects of G. lucidum are mediated through the inhibition of the transcriptional activation of estrogen receptor signaling, MCF-7 and MDA-MB-231 cells were transfected with reporter gene constructs ERE-luc, and treated with E2 (10 nM), TAM $(1 \mu \mathrm{M})$, and $G$. lucidum $(0.5 \mathrm{mg} / \mathrm{ml})$ for $24 \mathrm{~h}$, respectively. As seen in Fig. 3A, G. lucidum suppressed constitutive (control vs GL) as well as estrogen-induced (E2 vs E2 + GL) transcriptional activation in MCF-7 cells. Although G. lucidum and TAM inhibited the constitutive ERE activity in a similar manner, this effect was not additive or synergistic. Furthermore, G. lucidum inhibited also constitutive ERE activity (control vs GL) in MDA-MB-231 cells (Fig. 3B). As expected E2 does not stimulate ERE activity in MDA-MB-231 cells and also the effect of TAM was not so dramatic in these cells (Fig. 3B). To evaluate if the suppression of transcriptional activation through ERE is the result of the inhibition of the DNA-binding, we have performed gel shift analysis with nuclear extracts from MCF-7 and MDA-MB-231 cells with [32]P-labeled ERE DNA-binding oligonucleotide probe. As seen in Fig. 3C, nuclear extracts from MCF-7 cells bind specifically to the ERE, and G. lucidum inhibited ERE-binding. In addition, G. lucidum also inhibited ERE-binding in MDAMB-231 cells (not shown). In summary, G. lucidum inhibits ERE transactivation activity mediated through ER $\alpha$ and ERß in breast cancer cells.

G. lucidum inhibits constitutive as well as inducible $N F-\kappa B$ activity through estrogen receptor-independent as well as estrogen receptor-dependent pathways. The constitutive activation of NF- $\mathrm{KB}$ contributes to the progression of breast cancer to estrogen-independent growth and more aggressive phenotype of breast cancer cells $(28,29)$. We have previously demonstrated that $G$. lucidum decreased constitutively active $N F-\kappa B$ resulting in the cell cycle arrest at $G_{0} / G_{1}$ and inhibition of proliferation of MDA-MB-231 cells $(21,22)$. In order to evaluate the effect of G. lucidum on inducible NF-кB activation,
A

MCF-7

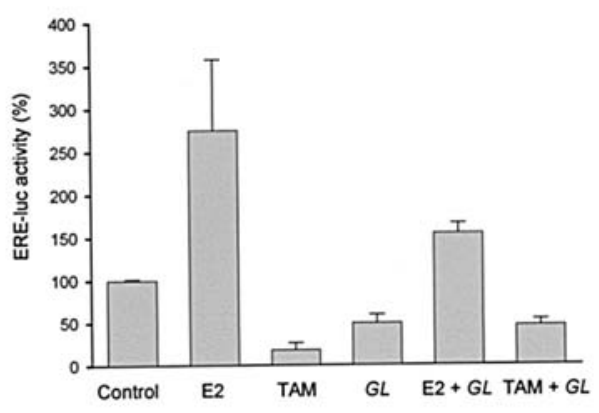

B

MDA-MB-231

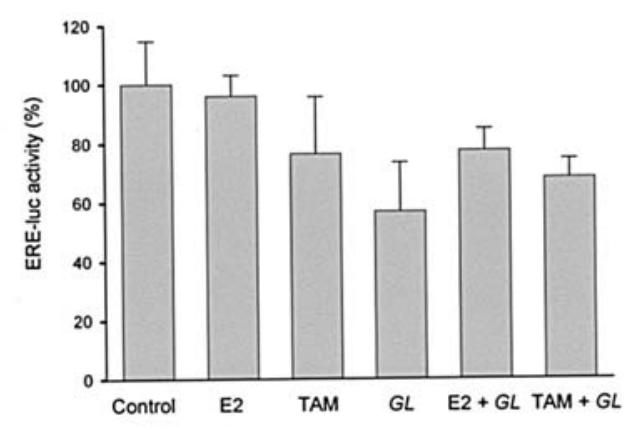

C

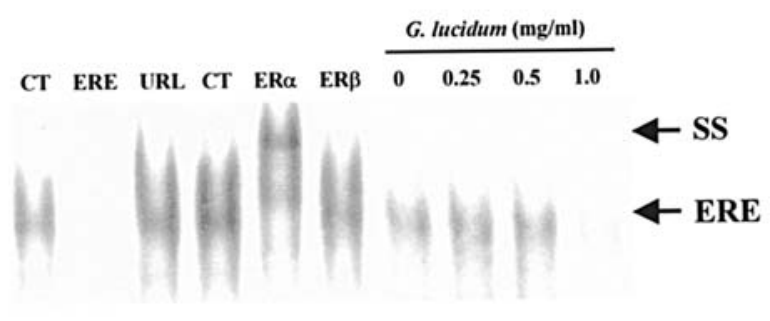

Figure 3. G. lucidum inhibits ERE activity in breast cancer cells. (A) MCF-7; (B) MDA-MB-231 cells were transfected with $1 \mu \mathrm{g}$ ERE-luc reporter gene construct and $1 \mu \mathrm{g}$ ß-galactosidase expression vector $\mathrm{pCH} 110$. Twenty-four hours after transfection, the cells were treated with vehicle (control), E2 $(10 \mathrm{nM})$, tamoxifen (TAM, $1 \mu \mathrm{M})$, G. lucidum (GL, $0.5 \mathrm{mg} / \mathrm{ml})$, or the combination of E2 with GL or TAM with GL for $24 \mathrm{~h}$. ERE activity was measured as described in Materials and methods. The results are expressed as the percentage of relative ERE activity. Each bar represents the mean \pm $\mathrm{SD}$ of three experiments. (C) MCF-7 cells were treated with G. lucidum $(0-1.0 \mathrm{mg} / \mathrm{ml})$ for $24 \mathrm{~h}$ and nuclear extracts were subjected to EMSA with $\left[{ }^{32} \mathrm{P}\right]$-labeled ERE probe as described in Materials and methods. The specificity was confirmed by competitive EMSA with cold ERE oligonucleotide or unrelated DNA (URL), and supershift analysis with anti$\mathrm{ER} \alpha$ or anti-ERß antibody. The results are representative of three separate experiments.

MCF-7 cells were transfected with reporter gene constructs NF-кB-luc, and treated with TNF- $\alpha$, E2, TAM and G. lucidum as described in Materials and methods. As expected, TNF- $\alpha$ stimulated NF- $\mathrm{KB}$ activity in MCF-7 cells, and this activity was inhibited by G. lucidum (Fig. 4A, control + TNF- $\alpha$ vs TNF- $\alpha+$ GL). In addition, E2 treatment further increased TNF- $\alpha$ stimulated NF-кB activity, which was also inhibited 
A

MCF-7

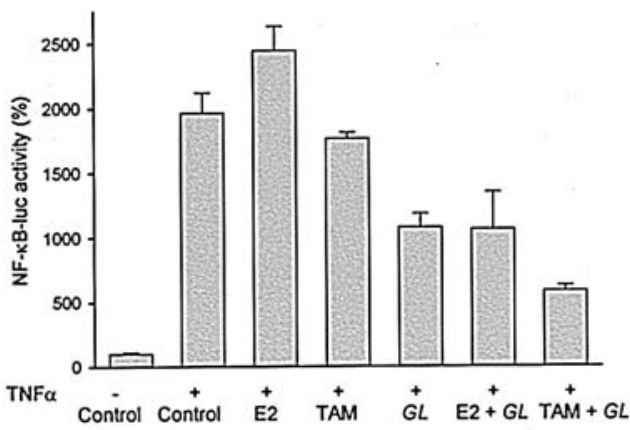

B

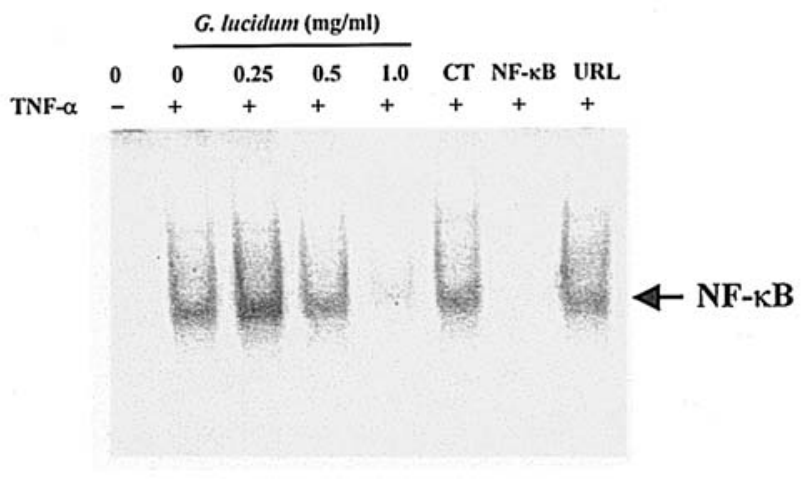

C

MDA-MB-231

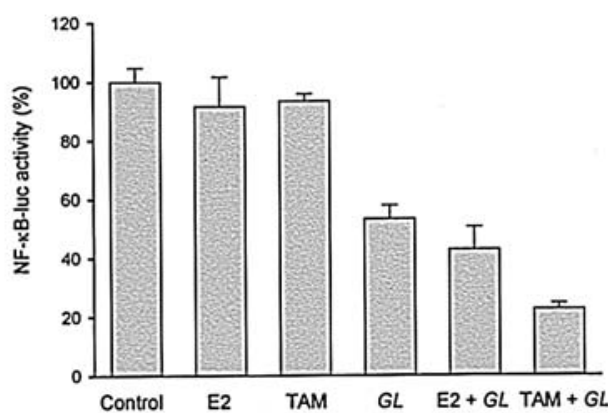

Figure 4. G. lucidum inhibits NF-кB activity in breast cancer cells. (A) MCF-7 cells were transfected with $1 \mu \mathrm{g} \mathrm{NF- \kappa B}-1$ luc reporter construct and $1 \mu \mathrm{g} \beta$-galactosidase expression vector $\mathrm{pCH} 110$. Twenty-four hours after transfection, the cells were treated with vehicle (control), E2 (10 nM), tamoxifen (TAM, $1 \mu \mathrm{M}$ ), G. lucidum (GL, $0.5 \mathrm{mg} / \mathrm{ml}$ ), or the combination of E2 with GL or TAM with GL for $20 \mathrm{~h}$, followed by a 4-h incubation with $\mathrm{TNF}-\alpha(50 \mathrm{ng} / \mathrm{ml})$. NF- $\mathrm{\kappa B}$ activity was measured as described in Materials and methods. The results are expressed as the percentage of relative NF-кB activity. Each bar represents the mean \pm SD of three experiments. (B) MCF-7 cells were treated with G. lucidum $(0-1.0 \mathrm{mg} / \mathrm{ml})$ for $20 \mathrm{~h}$ following by a $4-\mathrm{h}$ incubation with $\mathrm{TNF}-\alpha(50 \mathrm{ng} / \mathrm{ml})$, and nuclear extracts were subjected to EMSA with [ $\left.{ }^{32} \mathrm{P}\right]$-labeled NF- $\mathrm{BB}$ probe as described in Materials and methods. The specificity was confirmed by competitive EMSA with cold NF- $\kappa \mathrm{B}$ oligonucleotide or unrelated DNA (URL). The results are representative of three separate experiments. (C) MDA-MB-231 cells were transfected with $1 \mu \mathrm{g} \mathrm{NF- \kappa B}-1 \mathrm{c}$ reporter construct and $1 \mu \mathrm{g} ß$-galactosidase expression vector $\mathrm{pCH} 110$. Twenty-four hours after transfection, the cells were treated with vehicle (control), E2 (10 nM), tamoxifen (TAM, $1 \mu \mathrm{M})$, G. lucidum (GL, $0.5 \mathrm{mg} / \mathrm{ml}$ ), or the combination of E2 with GL or TAM with GL for $24 \mathrm{~h}$. $\mathrm{NF}-\kappa \mathrm{B}$ activity was measured as described in Materials and methods. The results are expressed as the percentage of relative NF- $\kappa \mathrm{B}$ activity. Each bar represents the mean $\pm \mathrm{SD}$ of three experiments.
A

HEK-293

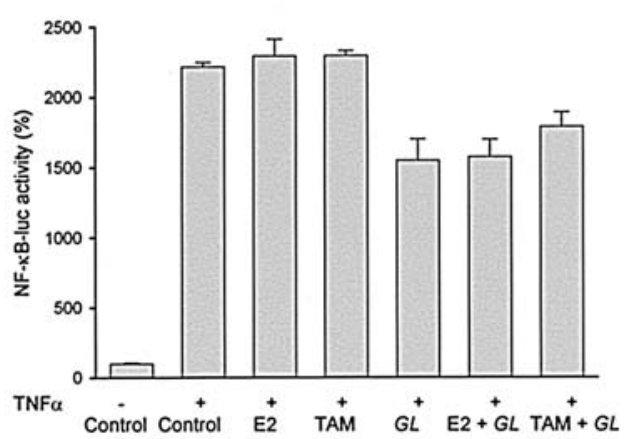

B

HEK-293 + ER $\alpha$

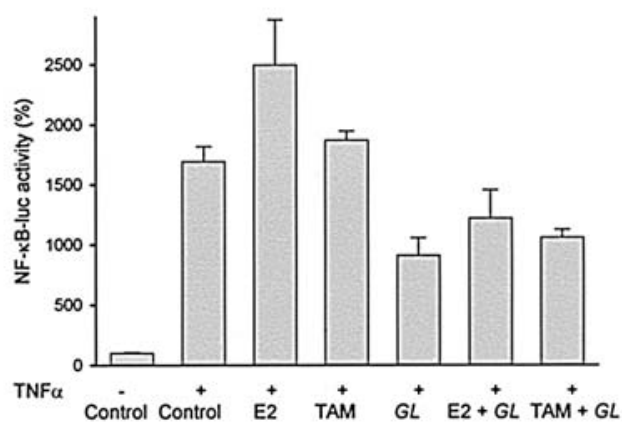

C

HEK-293 + ER $\beta$

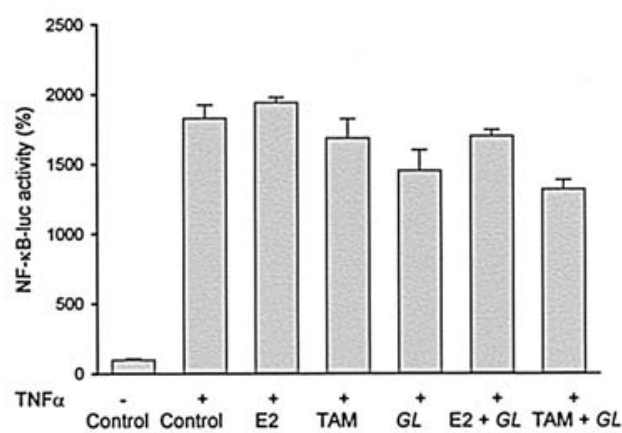

Figure 5. Effect of estrogen receptors on G. lucidum mediated inhibition of

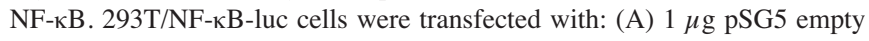
expression vector; (B) $1 \mu \mathrm{g}$ ER $\alpha$ expression vector; (C) $1 \mu \mathrm{g}$ ERß expression vector and $1 \mu \mathrm{g} \mathrm{B}$-galactosidase expression vector $\mathrm{pCH} 110$. Twenty-four hours after transfection, the cells were treated with E2 $(10 \mathrm{nM})$, tamoxifen (TAM, $1 \mu \mathrm{M}$ ), G. lucidum (GL, $0.5 \mathrm{mg} / \mathrm{ml}$ ) or the combination of $\mathrm{E} 2$ with GL or TAM with GL for $20 \mathrm{~h}$, followed by a 4-h incubation with TNF- $\alpha$ $(50 \mathrm{ng} / \mathrm{ml})$. NF- $\mathrm{kB}$ activity was measured as described in Materials and methods. The results are expressed as the percentage of relative NF-kB activity. Each bar represents the mean $\pm \mathrm{SD}$ of three experiments.

by the treatment with $G$. lucidum (Fig. $4 \mathrm{~A}, \mathrm{TNF}-\alpha+\mathrm{E} 2$ vs TNF- $\alpha+\mathrm{E} 2+\mathrm{GL})$, and tamoxifen further enhanced the inhibitory effect of G. lucidum (Fig. 4A, TNF- $\alpha$ vs TNF- $\alpha+$ TAM + GL). In order to confirm that G. lucidum inhibits DNA-binding of NF- $\mathrm{BB}$ in TNF- $\alpha$-stimulated MCF-7 cells, nuclear extracts were prepared and subjected to gel shift 
A
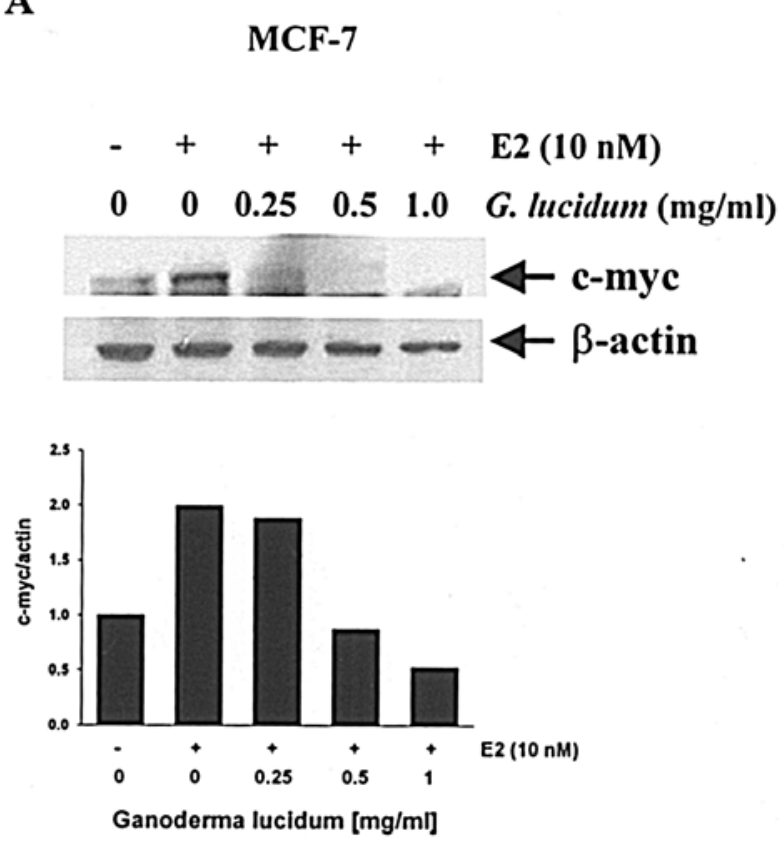

B

MDA-MB-231
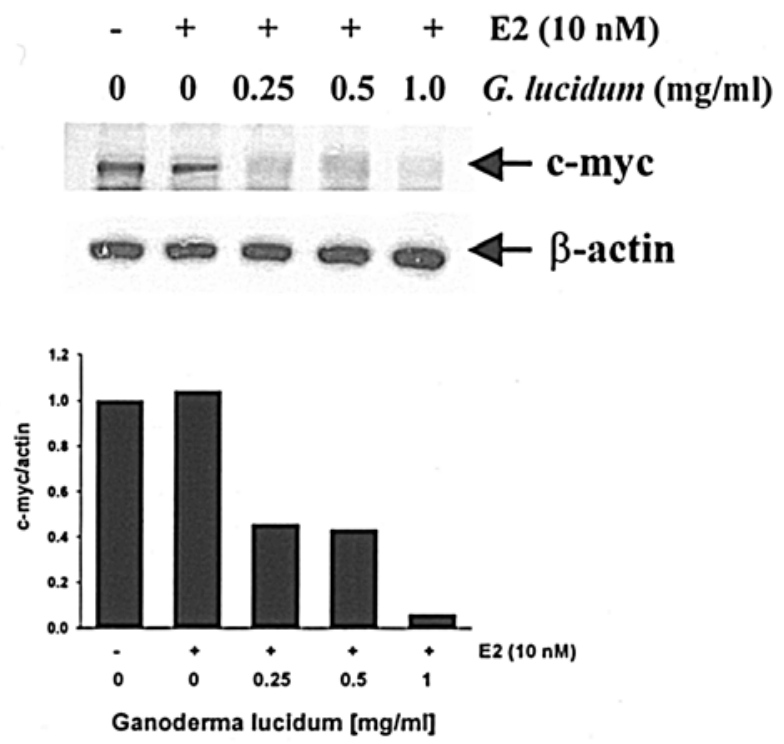

Figure 6. Effect of G. lucidum on the expression of c-myc in breast cancer cells. (A) MCF-7; (B) MDA-MB-231 cells were treated with E2 (10 nM) and G. lucidum $(0-1.0 \mathrm{mg} / \mathrm{ml})$ for $24 \mathrm{~h}$. Whole cell extracts were subjected to Western blot analysis with anti-c-myc antibody. The equal protein loading was verified with anti-ß-actin antibody and the expression of $c$-myc quantified by densitometry as described in Materials and methods. The results are representative of three separate experiments.

analysis with $\left[{ }^{32} \mathrm{P}\right]$-labeled $\mathrm{NF}-\kappa \mathrm{B}$ oligonucleotide probe. As seen in Fig. 4B, G. lucidum inhibits DNA-binding of inducible $\mathrm{NF}-\kappa \mathrm{B}$; the specificity of this inhibition was confirmed by competition and supershift assays (18). As we have previously reported, G. lucidum inhibits constitutively active NF-кB in MDA-MB-231 cells $(21,22)$. However, this effect can be enhanced by the combination of G. lucidum with tamoxifen (Fig. 4C, control vs GL vs TAM + GL).
In order to elucidate the role of estrogen receptors in the inhibition of NF-кB mediated by G. lucidum, we employed HEK-293 containing NF-кB-luciferase reporter gene (293T/NF-кB-luc). These cells do not express endogenous ER $\alpha$ or ERß, and G. lucidum markedly inhibited TNF- $\alpha$-induced NF-кB activity (Fig. 5A). Interestingly, E2 further stimulated TNF- $\alpha$-induced NF- $\mathrm{BB}$ activity in 293T/NF$\kappa \mathrm{B}-$ luc cells transfected with $\mathrm{ER} \alpha$, and this NF- $\mathrm{BB}$ activity was also suppressed by G. lucidum (Fig. 5B). Moreover, TNF- $\alpha$-induced NF- $\mathrm{BB}$ activity in $293 \mathrm{~T} / \mathrm{NF}-\kappa \mathrm{B}-\mathrm{luc}$ cells transfected with ERß was also decreased by G. lucidum (Fig. 5C).

In summary, G. lucidum inhibits constitutive as well as inducible activation of NF-кB, and this inhibition can be mediated through $\mathrm{ER} \alpha$ or $\mathrm{ER} \beta$, or can be estrogen receptor independent.

G. lucidum down-regulates expression of c-myc in breast cancer cells. Increased expression of the oncogene c-myc has been detected in a majority of breast cancers (13). Because the expression of c-myc is controlled by estrogen and by NF-кB (15-17), we hypothesized that G. lucidum also modulates expression of c-myc in breast cancer cells. Although estradiol markedly induced expression of c-myc in MCF-7 cells, G. lucidum down-regulated expression of c-myc in a dose response manner (Fig. 6A). As expected, E2 did not stimulate c-myc expression in estrogen-independent MDAMB-231 cells, and the constitutive c-myc expression was also down-regulated by G. lucidum in a dose-response manner (Fig. 6B). These results suggest that the inhibitory effects of G. lucidum on the growth of MCF-7 and MDA-MB-231 cells can be associated with the down-regulation of estrogendependent as well as estrogen-independent expression of c-myc.

\section{Discussion}

We have previously demonstrated that $G$. lucidum inhibits invasive behavior and proliferation of highly metastatic estrogen-independent breast cancer cells through the suppression of constitutively active NF-кB $(21,22,30)$. Nevertheless, the effect of G. lucidum on the most pertinent signaling network involved in breast cancer - estrogen receptor signaling, remains to be elucidated. In the present study, we evaluated the effect of G. lucidum on the estrogen-dependent, poorly invasive breast cancer cells (MCF-7) and estrogen-independent, highly invasive breast cancer cells (MDA-MB-231). We showed that G. lucidum can mediate, in part, its antiproliferative effect through the inhibition of ER and NF-кB signaling, resulting in the down-regulation of expression of c-myc in breast cancer cells (Fig. 7).

Estrogen receptor signaling is a complex process, which can be controlled at the level of expression of estrogen receptor or at the level of its function as a transcription factor regulating expression of estrogen-responsive genes. Here we show that G. lucidum down-regulated the expression of ER $\alpha$ in MCF-7 cells. This effect was specific for ER $\alpha$ because the expression of ERß in MCF-7 or MDA-MB-231 cells was not affected by the G. lucidum treatment. Since estrogen activities responsible for cell proliferation of breast cancer 


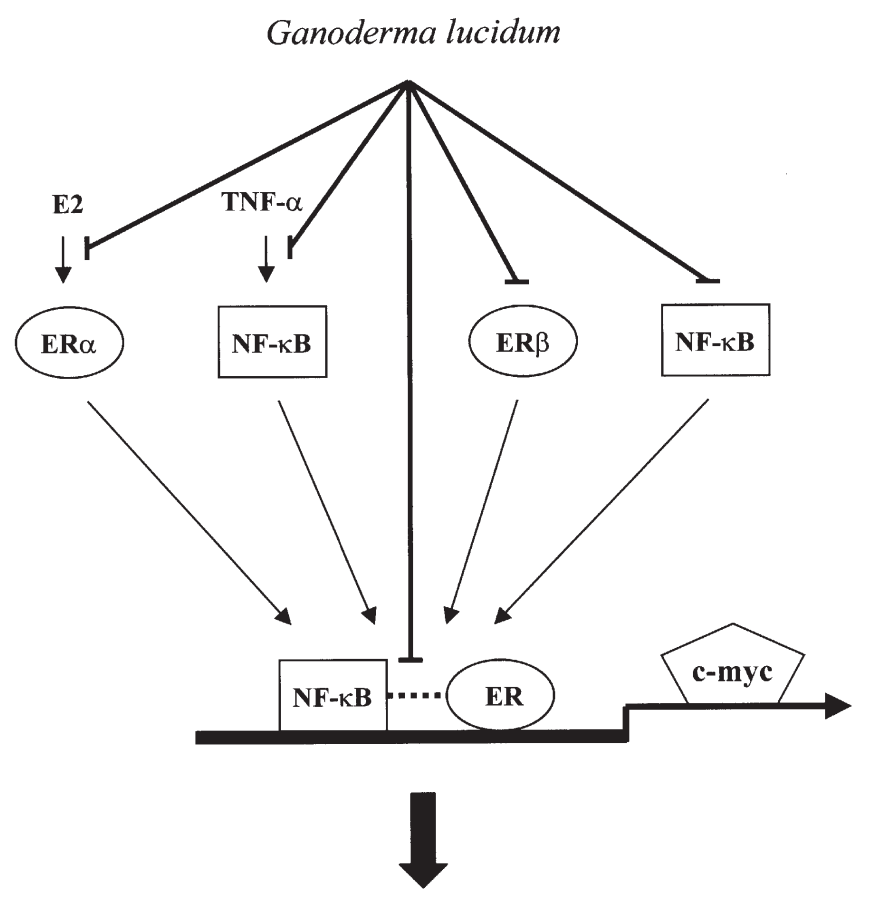

\section{Proliferation of estrogen-dependent and estrogen-independent breast cancer cells}

Figure 7. Proposed mechanisms for the inhibition of proliferation in estrogendependent and estrogen-independent breast cancer cells by G. lucidum. In estrogen-dependent MCF-7 cells, G. lucidum down-regulates the expression of ER $\alpha$, inhibits E2-induced activation of ER $\alpha$, and inhibits TNF- $\alpha$-induced activation of NF-кB. In estrogen-independent MDA-MB-231 cells, G. lucidum inhibits constitutive trans-activation of ERß and NF-кB. G. lucidum also inhibits possible interaction between $\mathrm{NF}-\kappa \mathrm{B}$ and estrogen receptor, resulting in the down-regulation of expression of c-myc and inhibition of growth of human breast cancer cells.

cells are mediated through ER $\alpha$ (31), the down-regulation of $\mathrm{ER} \alpha$ by G. lucidum resulted in the inhibition of proliferation of ER $\alpha$-positive breast cancer cells. In contrast, G. lucidum did not down-regulate expression of ERß suggesting that $G$. lucidum inhibits proliferation of ERß-positive cells independently of ERß. Furthermore, G. lucidum suppressed growth of MDA-MB-231 through the inhibition of Akt/NF$\kappa \mathrm{B}$ signaling (22). Finally, the down-regulation of expression of ER $\alpha$ by ethanol extract of G. lucidum was also demonstrated in prostate cancer cells (32).

At the transcription level, G. lucidum suppressed estrogen signaling by the inhibition of transactivation of estrogen receptor using reporter gene construct linked to the estrogen response element (ERE). Therefore, G. lucidum inhibits constitutive as well as E2-induced ERE transactivation in estrogen-dependent MCF-7 cells, and constitutive ERE transactivation in estrogen-independent MDA-MB-231 cells. The suppression of transcriptional activity through ER $\alpha$ and ERß by G. lucidum, suggests that G. lucidum triterpenes could exert selective estrogen receptor modulator (SERM) activities. However, due to the complex composition of $G$. lucidum extract, containing polysaccharides and triterpenes, we were not able to detect specific binding to ER (not shown). Interestingly, structurally related triterpenes isolated from the plant Ferula modulated estrogenic activity also through the interaction with $\mathrm{ER} \alpha$ and $\mathrm{ER} \beta$ (33). In addition, markedly lower doses of G. lucidum inhibited proliferation of MCF-7 (ER $\alpha$-positive, ERß-positive) than of MDA-MB-231 (ER $\alpha$ negative, ERß-positive) cells. This effect was mimicked by the typical SERM anti-estrogen tamoxifen, which inhibits ER $\alpha$-negative breast cancer cells only at higher concentrations (34). Furthermore, inhibition of proliferation of breast cancer cells by $G$. lucidum is mediated by the cell cycle arrest at $\mathrm{G}_{0} / \mathrm{G}_{1}(22)$, which is a typical mechanism for anti-estrogens regulation of cell cycle (35).

We have previously demonstrated that G. lucidum inhibits constitutively active NF- $\mathrm{KB}$ in MDA-MB-231 cells (21). In the present study we show that G. lucidum also inhibits inducible activation of $\mathrm{NF}-\kappa \mathrm{B}$ independently of status of estrogen receptor in cells. Thus, G. lucidum inhibited NF-кB in cells which do not express ER (HEK-293), in cells expressing ER $\alpha$ (HEK-293 overexpressing ER $\alpha$ ), in cells expressing ERß (MDA-MB-231 and HEK-293 overexpressing ERß) or in cells expressing ER $\alpha$ and ERß (MCF-7). However, estradiol and TNF- $\alpha$-stimulated NF-кB activity was inhibited by G. lucidum only in cells expressing ER $\alpha$, suggesting that G. lucidum modulates cross-talk between ER and NF-кB. Although the original model of the interaction between $N F-\kappa B$ and $E R \alpha$ suggested inhibition of NF-кB by E2 (36), here we demonstrate that $\mathrm{E} 2$ in fact, under certain conditions, may also induce $\mathrm{NF}-\kappa \mathrm{B}$. Furthermore, the positive regulation of NF-кB- and $\mathrm{ER} \alpha$-responsive genes c-myc and cyclin D1, via the promoter association of IкB kinase (IKK $\alpha$ and $E R \alpha$ ), resulted in the enhanced proliferation of breast cancer cells (37).

We demonstrate that G. lucidum down-regulated the E2dependent as well as constitutive expression of c-myc in breast cancer cells. The inhibition of E2-stimulated c-myc expression in ER $\alpha$-positive cells is consistent with our data demonstrating inhibition of E2-dependent trans-activation activity in MCF-7 cells by G. lucidum. Given that tamoxifen inhibits proliferation and c-myc expression in ER $\alpha$-positive breast cancer cells (38-40) our data further suggest an antiestrogenic effect of G. lucidum. However, the downregulation of c-myc, which is constitutively active and is not activated by $\mathrm{E} 2$ in ER $\alpha$-negative breast cancer cells, demonstrates the inhibitory effect of G. lucidum also on $\mathrm{NF}-\kappa \mathrm{B}$ pathway.

In conclusion, we present a possible mechanism by which G. lucidum inhibits proliferation of estrogen-dependent as well as estrogen-independent human breast cancer cells. The biological effects of G. lucidum on estrogen-dependent MCF-7 cells are mediated through the down-regulation of ER $\alpha$ expression, inhibition of estrogen-inducible ER transactivation and inhibition of TNF- $\alpha$-stimulated activation of NF-кB. The effects on estrogen-independent MDA-MB-231 cells are mediated through the suppression of constitutive activity of ERE and NF- $\mathrm{KB}$. The inhibition of inducible- as well as constitutive ER and NF- $\mathrm{B}$ pathways results in the down-regulation of expression of c-myc, finally resulting in the suppression of proliferation of estrogen-dependent and estrogen-independent human breast cancer cells. Further studies are in progress to identify biologically active compounds in G. lucidum with specificity against estrogen receptor and $\mathrm{NF}-\kappa \mathrm{B}$ signaling. 


\section{Acknowledgements}

This work was supported by a grant from Methodist Health Foundation to D.S. We thank Dr Jan-Åke Gustafsson for ERß expression vector, and Dr Peter Kushner for the ERE-IIluc reporter gene construct.

\section{References}

1. Foster JS, Henley DC, Ahamed S and Wimalasena J: Estrogens and cell-cycle regulation in breast cancer. Trends Endocrinol Metab 12: 320-327, 2001.

2. Segars JH and Driggers PH: Estrogen action and cytoplasmic signaling cascades. Part I: membrane-associated signaling complexes. Trends Endocrinol Metab 13: 349-354, 2002.

3. Doisneau-Sixou SF, Sergio CM, Carroll JS, Hui R, Musgrove EA and Sutherland RL: Estrogen and antiestrogen regulation of cell cycle progression in breast cancer cells. Endocr Relat Cancer 10: 179-186, 2003.

4. Hayashi SI, Eguchi H, Tanimoto K, Yoshida T, Omoto Y, Inoue $\mathrm{A}$, Yoshida $\mathrm{N}$ and Yamaguchi $\mathrm{Y}$ : The expression and function of estrogen receptor alpha and beta in human breast cancer and its clinical application. Endocr Relat Cancer 10: 193-202, 2003.

5. Simoncini T, Mannella P, Fornari L, Caruso A, Varone G and Genazzani AR: Genomic and non-genomic effects of estrogens on endothelial cells. Steroids 69: 537-542, 2004.

6. Osborne CK and Schiff R: Estrogen-receptor biology: continuing progress and therapeutic implications. J Clin Oncol 23: 1616-1622, 2005.

7. Paech K, Webb P, Kuiper GG, Nilsson S, Gustafsson J, Kushner PJ and Scanlan TS: Differential ligand activation of estrogen receptors ERalpha and ERbeta at AP1 sites. Science 277: 1508-1510, 1997.

8. Liu MM, Albanese C, Anderson CM, Hilty K, Webb P, Uht RM, Price RH Jr, Pestell RG and Kushner PJ: Opposing action of estrogen receptors alpha and beta on cyclin D1 gene expression. J Biol Chem 277: 24353-24360, 2002.

9. Weihua Z, Saji S, Makinen S, Cheng G, Jensen EV, Warner M and Gustafsson JA: Estrogen receptor (ER) beta, a modulator of ERalpha in the uterus. Proc Natl Acad Sci USA 97: 5936-5941, 2000 .

10. Clarke R, Liu MC, Bouker KB, Gu Z, Lee RY, Zhu Y, Skaar TC, Gomez B, O'Brien K, Wang Y and Hilakivi-Clarke LA: Antiestrogen resistance in breast cancer and the role of estrogen receptor signaling. Oncogene 22: 7316-7339, 2003.

11. Pasqualini JR: The selective estrogen enzyme modulators in breast cancer: a review. Biochim Biophys Acta 1654: 123-143, 2004.

12. Biswas DK, Dai SC, Cruz A, Weiser B, Graner E and Pardee AB: The nuclear factor kappa B (NF-kappa B): a potential therapeutic target for estrogen receptor negative breast cancers. Proc Natl Acad Sci USA 98: 10386-10391, 2001.

13. Liao DJ and Dickson RB: c-Myc in breast cancer. Endocr Relat Cancer 7: 143-164, 2000.

14. Kim DW, Sovak MA, Zanieski G, Nonet G, Romieu-Mourez R, Lau AW, Hafer LJ, Yaswen P, Stampfer M, Rogers AE, Russo J and Sonenshein GE: Activation of NF-kappaB/Rel occurs early during neoplastic transformation of mammary cells. Carcinogenesis 21:871-879, 2000

15. Dubik D and Shiu RP: Mechanism of estrogen activation of c-myc oncogene expression. Oncogene 7: 1587-1594, 1992.

16. Schuchard M, Landers JP, Sandhu NP and Spelsberg TC: Steroid hormone regulation of nuclear proto-oncogenes. Endocr Rev 14: 659-669, 1993.

17. La Rosa FA, Pierce JW and Sonenshein GE: Differential regulation of the c-myc oncogene promoter by the NF-kappa B rel family of transcription factors. Mol Cell Biol 14: 1039-1044, 1994.

18. Sliva D, Rizzo MT and English D: Phosphatidylinositol 3-kinase and NF-kappaB regulate motility of invasive MDA-MB-231 human breast cancer cells by the secretion of urokinase-type plasminogen activator. J Biol Chem 277: 3150-3157, 2002.

19. Gao JJ, Min BS, Ahn EM, Nakamura N, Lee H K and Hattori M: New triterpene aldehydes, lucialdehydes A-C, from Ganoderma lucidum and their cytotoxicity against murine and human tumor cells. Chem Pharm Bul 50: 837-840, 2002.

20. Gao Y and Zhou S: Cancer prevention and treatment by Ganoderma, a mushroom with medicinal properties. Food Rev Int 19: 275-325, 2003.
21. Sliva D, Labarrere C, Slivova V, Sedlak M, Lloyd FP Jr and Ho NW: Ganoderma lucidum suppresses motility of highly invasive breast and prostate cancer cells. Biochem Biophys Res Commun 298: 603-612, 2002.

22. Jiang J, SlivovaV, Harvey K, Valachovicova T and Sliva D: Ganoderma lucidum suppresses growth of breast cancer cells through the inhibition of Akt/NF-kappaB signaling. Nutr Cancer 49: 209-216, 2004.

23. Jiang J, Sugimoto Y, Liu S, Chang HL, Park KY, Kulp SK and Lin YC: The inhibitory effects of gossypol on human prostate cancer cells-PC3 are associated with transforming growth factor beta1 (TGFbeta1) signal transduction pathway. Anticancer Res 24: 91-100, 2004.

24. Lee SO, Nadiminty N, Wu XX, Lou W, Dong Y, Ip C, Onate SA and Gao AC: Selenium disrupts estrogen signaling by altering estrogen receptor expression and ligand binding in human breast cancer cells. Cancer Res 65: 3487-3492, 2005.

25. Tora L, Mullick A, Metzger D, Ponglikitmongkol M, Park I and Chambon P: The cloned human oestrogen receptor contains a mutation which alters its hormone binding properties. EMBO J 8: 1981-1986, 1989.

26. Ogawa S, Inoue S, Watanabe T, Hiroi H, Orimo A, Hosoi T, Ouchi $\mathrm{Y}$ and Muramatsu M: The complete primary structure of human estrogen receptor beta (hER beta) and its heterodimerization with ER alpha in vivo and in vitro. Biochem Biophys Res Commun 243: 122-126, 1998.

27. Kuiper GG, Lemmen JG, Carlsson B, Corton JC, Safe SH, van der Saag PT, van der Burg B and Gustafsson JA: Interaction of estrogenic chemicals and phytoestrogens with estrogen receptor beta. Endocrinology 139: 4252-4263, 1998.

28. Nakshatri H, Bhat-Nakshatri P, Martin DA, Goulet RJ Jr and Sledge GW Jr: Constitutive activation of NF-kappaB during progression of breast cancer to hormone-independent growth. Mol Cell Biol 17: 3629-3639, 1997.

29. Sovak MA, Bellas RE, Kim DW, Zanieski GJ, Rogers AE, Traish AM and Sonenshein GE: Aberrant nuclear factor$\mathrm{kappaB} /$ Rel expression and the pathogenesis of breast cancer. J Clin Invest 100: 2952-2960, 1997.

30. Slivova V, Valachovicova T, Jiang J and Sliva D: Ganoderma lucidum inhibits invasiveness of breast cancer cells. J Cancer Integ Med 2: 25-30, 2004.

31. Sun JM, Chen HY and Davie JR: Effect of estradiol on histone acetylation dynamics in human breast cancer cells. J Biol Chem 276: 49435-49442, 2001.

32. Hsieh TC and Wu JM: Mechanism of action of herbal supplement PC-SPES: elucidation of effects of individual herbs of PC-SPES on proliferation and prostate specific gene expression in androgendependent LNCaP cells. Int J Oncol 20: 583-588, 2002.

33. Ikeda K, Arao Y, Otsuka H, Nomoto S, Horiguchi H, Kato S and Kayama F: Terpenoids found in the umbelliferae family act as agonists/antagonists for ER(alpha) and ERbeta: differential transcription activity between ferutinine-liganded ER(alpha) and ERbeta. Biochem Biophys Res Commun 291: 354-360, 2002.

34. Chen $J$ and Thompson LU: Lignans and tamoxifen, alone or in combination, reduce human breast cancer cell adhesion, invasion and migration in vitro. Breast Cancer Res Treat 80: 163-170, 2003.

35. Taylor IW, Hodson PJ, Green MD and Sutherland RL: Effects of tamoxifen on cell cycle progression of synchronous MCF-7 human mammary carcinoma cells. Cancer Res 43: 4007-4010, 1983.

36. Nilsson S, Makela S, Treuter E, Tujague M, Thomsen J, Andersson G, Enmark E, Pettersson K, Warner M and Gustafsson JA: Mechanisms of estrogen action. Physiol Rev 81: 1535-1565, 2001.

37. Park KJ, Krishnan V, O'Malley BW, Yamamoto Y and Gayno RB: Formation of an IKKalpha-dependent transcription complex is required for estrogen receptor-mediated gene activation. Mol Cell 18: 71-82, 2005.

38. Wong MS and Murphy LC: Differential regulation of c-myc by progestins and antiestrogens in T-47D human breast cancer cells. J Steroid Biochem Mol Biol 39: 39-44, 1991.

39. Le Roy X, Escot C, Brouillet JP, Theillet C, Maudelonde T, Simony-Lafontaine J, Pujol H and Rochefort H: Decrease of c-erbB-2 and c-myc RNA levels in tamoxifen-treated breast cancer. Oncogene 6: 431-437, 1991.

40. Tsai LC, Hung MW, Yuan CC, Chao PL, Jiang SY, Chang GG and Chang TC: Effects of tamoxifen and retinoic acid on cell growth and c-myc gene expression in human breast and cervical cancer cells. Anticancer Res 17: 4557-4562, 1997. 